\title{
Celiac disease-epilepsy-cerebral calcification syndrome
}

INSERM

\section{Source}

INSERM. (1999). Orphanet: an online rare disease and orphan drug data base. Celiac disease-epilepsy-cerebral calcification syndrome. ORPHA:1459

Celiac disease, epilepsy and cerebral calcification syndrome (CEC) is a rare disorder characterized by the combination of auto-immune intestinal disease, epileptic seizures and cerebral calcifications. 